\title{
Papers
}

\section{Tight blood pressure control and risk of macrovascular and microvascular complications in type 2 diabetes: UKPDS 38}

\author{
UK Prospective Diabetes Study Group
}

\begin{abstract}
Objective: To determine whether tight control of blood pressure prevents macrovascular and microvascular complications in patients with type 2 diabetes.

Design: Randomised controlled trial comparing tight control of blood pressure aiming at a blood pressure of $<150 / 85 \mathrm{~mm} \mathrm{Hg}$ (with the use of an angiotensin converting enzyme inhibitor captopril or a $\beta$ blocker atenolol as main treatment) with less tight control aiming at a blood pressure of $<180 / 105 \mathrm{~mm} \mathrm{Hg}$. Setting: 20 hospital based clinics in England, Scotland, and Northern Ireland.

Subjects: 1148 hypertensive patients with type 2 diabetes (mean age 56, mean blood pressure at entry 160/94 mm Hg); 758 patients were allocated to tight control of blood pressure and 390 patients to less tight control with a median follow up of 8.4 years. Main outcome measures: Predefined clinical end points, fatal and non-fatal, related to diabetes, deaths related to diabetes, and all cause mortality. Surrogate measures of microvascular disease included urinary albumin excretion and retinal photography.

Results: Mean blood pressure during follow up was significantly reduced in the group assigned tight blood pressure control (144/82 mm Hg) compared with the group assigned to less tight control $(154 / 87 \mathrm{~mm} \mathrm{Hg})(\mathrm{P}<0.0001)$. Reductions in risk in the group assigned to tight control compared with that assigned to less tight control were $24 \%$ in diabetes related end points $(95 \%$ confidence interval $8 \%$ to $38 \%)(\mathrm{P}=0.0046), 32 \%$ in deaths related to diabetes $(6 \%$ to $51 \%)(\mathrm{P}=0.019), 44 \%$ in strokes $(11 \%$ to $65 \%)(\mathrm{P}=0.013)$, and $37 \%$ in microvascular end points $(11 \%$ to $56 \%)(\mathrm{P}=0.0092)$, predominantly owing to a reduced risk of retinal photocoagulation. There was a non-significant reduction in all cause mortality. After nine years of follow up the group assigned to tight blood pressure control also had a $34 \%$ reduction in risk in the proportion of patients with deterioration of retinopathy by two steps (99\% confidence interval $11 \%$ to $50 \%)(\mathrm{P}=0.0004)$ and a $47 \%$ reduced risk $(7 \%$ to $70 \%)(\mathrm{P}=0.004)$ of deterioration in visual acuity by three lines of the early treatment of diabetic retinopathy study (ETDRS) chart. After nine years of follow up $29 \%$ of patients in
\end{abstract}

the group assigned to tight control required three or more treatments to lower blood pressure to achieve target blood pressures.

Conclusion: Tight blood pressure control in patients with hypertension and type 2 diabetes achieves a clinically important reduction in the risk of deaths related to diabetes, complications related to diabetes, progression of diabetic retinopathy, and deterioration in visual acuity.

\section{Introduction}

Type 2 diabetes and hypertension are commonly associated conditions, both of which carry an increased risk of cardiovascular and renal disease. ${ }^{1-6}$ The prevalence of hypertension in type 2 diabetes is higher than that in the general population, especially in younger patients. $^{7-9}$ At the age of 45 around $40 \%$ of patients with type 2 diabetes are hypertensive, the proportion increasing to $60 \%$ by the age of $75 .^{7-9}$ Hypertension increases the already high risk of cardiovascular disease associated with type 2 diabetes ${ }^{236}{ }^{10}$ and is also a risk factor for the development of microalbuminuria $^{11}{ }^{12}$ and retinopathy. ${ }^{13}$

In the general population treatment to lower blood pressure reduces the incidence of stroke and myocardial infarction, ${ }^{14}{ }^{15}$ particularly in elderly people. ${ }^{16}{ }^{17}$ In patients with type 1 diabetes who have microalbuminuria or overt nephropathy strict control of blood pressure reduces urinary albumin excretion and deterioration in renal function. ${ }^{18}{ }^{19}$ Lowering blood pressure also decreases albuminuria in type 2 diabetes, ${ }^{20}$ but whether it also reduces the risk of end stage renal disease or of cardiac disease is not known.

We report results from the hypertension in diabetes study, a multicentre, randomised, controlled trial (embedded within the UK prospective diabetes study) designed to determine whether tight blood pressure control (aiming for a blood pressure of $<150 / 85 \mathrm{~mm} \mathrm{Hg}$ ) reduces morbidity and mortality in hypertensive patients with type 2 diabetes. ${ }^{21}$

\section{Subjects and methods}

We studied hypertensive patients with type 2 diabetes who had been recruited to the UK prospective diabetes study. ${ }^{22}{ }^{23}$ General practitioners were asked to refer

\section{Editorials by \\ Orchard and Mogensen Papers pp 713, 720 \\ Members of the study group are given at the end of the paper. \\ This paper was prepared for publication by Robert Turner, Rury Holman, Irene Stratton, Carole Cull, Valeria Frighi, Susan Manley, David Matthews, Andrew Neil, Heather McElroy, \\ Eva Kohner, Charles Fox, David Hadden, and David Wright. \\ Correspondence to: Professor R Turner, UK Prospective Diabetes Study Group, Diabetes Research Laboratories, Radcliffe Infirmary, Oxford OX2 6HE}

BMJ 1998;317:703-13 


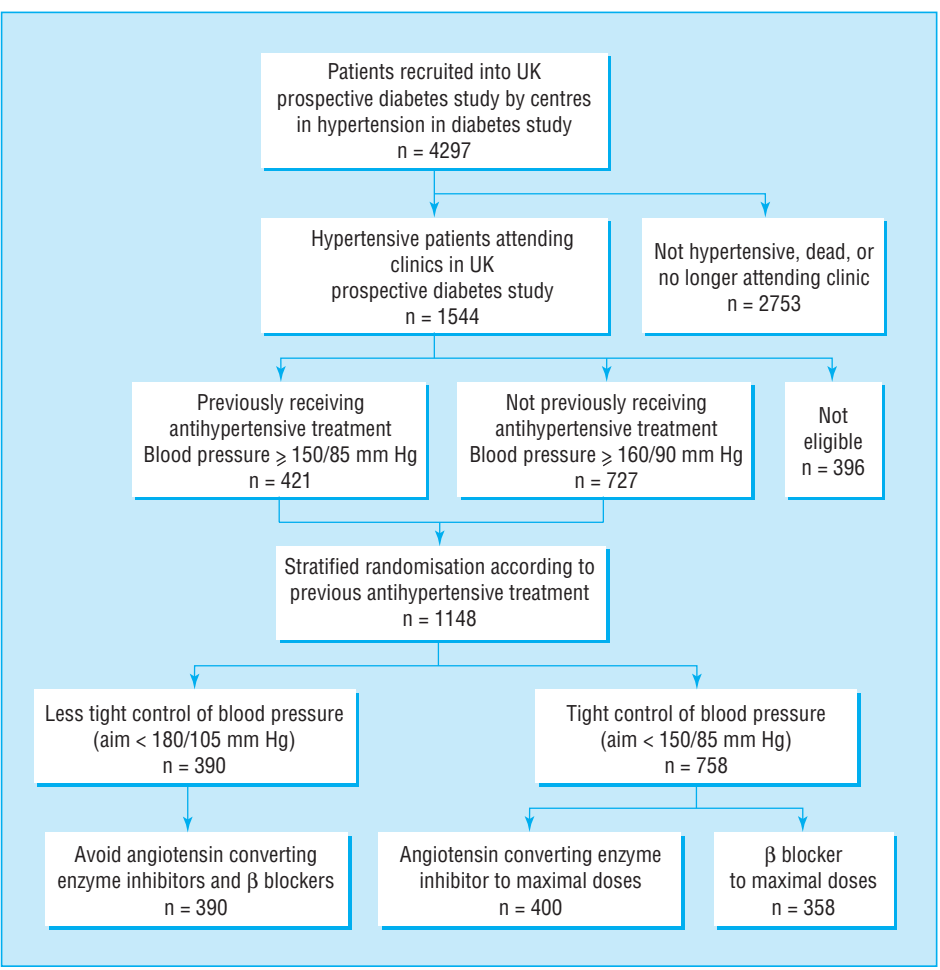

Fig 1 Selection and random allocation of patients to treatment in hypertension in diabetes study

patients aged 25-65 with newly diagnosed diabetes to 23 participating centres. A total of 5102 were recruited as they met the study's entry criterion (fasting plasma glucose concentration $>6 \mathrm{mmol} / \mathrm{l}$ on two mornings), were willing to join, and did not meet the exclusion criteria for the study. Exclusion criteria were ketonuria $>3 \mathrm{mmol} / \mathrm{l}$; a history of myocardial infarction in the previous year; current angina or heart failure; more than one major vascular episode; serum creatinine concentration $>175 \mu \mathrm{mol} / \mathrm{l}$; retinopathy requiring laser treatment; malignant hypertension; an uncorrected endocrine abnormality; an occupation which would preclude insulin treatment (such as heavy goods vehicle driver); a severe concurrent illness likely to limit life or require extensive systemic treatment; or inadequate understanding or unwillingness to enter the study. ${ }^{23}$ The patients were treated by diet alone for 3 months. ${ }^{24}$ Patients who remained hyperglycaemic (fasting plasma glucose $6.1-15.0 \mathrm{mmol} / \mathrm{l}$ ) without diabetic symptoms were randomly allocated conventional blood glucose control, primarily by diet, or intensive control (aiming for a fasting plasma glucose concentration $<6.0 \mathrm{mmol} / \mathrm{l})$ with additional sulphonylurea, insulin, or metformin treatment. Details of the protocol are published. ${ }^{22} 23$

Of the 4297 patients recruited to the 20 centres participating in the hypertension in diabetes study, 243 had either died or were lost to follow up before the start of the hypertension study in 1987 (fig 1). Of the remaining 4054 patients, $1544(38 \%)$ had hypertension, defined in 727 patients as a systolic blood pressure $\geqslant 160 \mathrm{~mm} \mathrm{Hg}$ and/or a diastolic blood pressure $\geqslant 90 \mathrm{~mm} \mathrm{Hg}$ or in 421 patients receiving antihypertensive treatment as a systolic pressure of $\geqslant 150 \mathrm{~mm} \mathrm{Hg}$ and/or a diastolic pressure $\geqslant 85 \mathrm{~mm} \mathrm{Hg}$ (fig 1). Patients were enrolled on the basis of the mean of three blood pressure measurements taken at consecutive clinic visits. The exclusion criteria were a clinical requirement for strict blood pressure control (previous stroke, accelerated hypertension, cardiac failure, or renal failure) or $\beta$ blockade (myocardial infarction in the previous year or current angina); severe vascular disease (more than one major vascular episode); a severe concurrent illness or contraindications to $\beta$ blockers (asthma, intermittent claudication, foot ulcers, or amputations); pregnancy; or unwillingness to join the study. Of the 1544 hypertensive patients, 252 were excluded and 144 patients did not enter the study. A total of 1148 patients (637 men $(55 \%))$ with a mean age of 56.4 (SD 8.1) years entered the hypertension in diabetes study between 1987 and 1991. ${ }^{21}$ Table 1 shows their characteristics at randomisation to blood pressure control policy.

Table 1 Characteristics of patients allocated to tight and less tight control of blood pressure. Values are numbers (percentages) of patients unless stated otherwise

\begin{tabular}{|c|c|c|}
\hline & $\begin{array}{c}\text { Tight } \\
(\mathrm{n}=758)\end{array}$ & $\begin{array}{l}\text { Less tight } \\
(\mathrm{n}=390)\end{array}$ \\
\hline Mean (SD) age (years) & $56.4(8.1)$ & $56.5(8.1)$ \\
\hline Male sex & $410(54)$ & $227(58)$ \\
\hline \multicolumn{3}{|l|}{ Ethnic group: } \\
\hline White & $651(86)$ & $344(88)$ \\
\hline Afro-Caribbean & $62(8)$ & $25(6)$ \\
\hline Asian Indian & $39(5)$ & $17(4)$ \\
\hline Other & $6(1)$ & $4(1)$ \\
\hline Mean (SD) body mass index $\left(\mathrm{kg} / \mathrm{m}^{2}\right)$ & $29.8(5.5)$ & $29.3(5.5)$ \\
\hline $\begin{array}{l}\text { Median (interquartile range) fasting } \\
\text { plasma glucose }(\mathrm{mmol} / \mathrm{l})\end{array}$ & $7.4(6.1$ to 9.2$)$ & $7.4(6.2$ to 9.8$)$ \\
\hline Mean $(\mathrm{SD})$ haemoglobin $\mathrm{A}_{1 \mathrm{c}}(\%)$ & $6.9(1.7)$ & $6.8(1.5)$ \\
\hline \multicolumn{3}{|l|}{ Mean (SD) blood pressure $(\mathrm{mm} \mathrm{Hg})$ : } \\
\hline Systolic & $159(20)$ & $160(18)$ \\
\hline Diastolic & $94(10)$ & $94(9)$ \\
\hline Receiving antihypertensive treatment & $286(36)$ & $145(37)$ \\
\hline \multicolumn{3}{|l|}{ Smoking: } \\
\hline No of patients & 746 & 379 \\
\hline Non-smoker & $281(38)$ & $142(38)$ \\
\hline Ex-smoker & $294(39)$ & $152(40)$ \\
\hline Current smoker & $171(23)$ & $85(22)$ \\
\hline \multicolumn{3}{|l|}{ Urinary albumin $\left(\mathrm{mg} / \mathrm{l}^{\star}\right.$ : } \\
\hline$\geqslant 50$ & $114(18)$ & $53(16)$ \\
\hline$\geqslant 300$ & $18(3)$ & $13(4)$ \\
\hline \multicolumn{3}{|l|}{ Retinopathy: } \\
\hline No of patients & 617 & 312 \\
\hline 2020 or worse & $143(23)$ & $89(29)$ \\
\hline 3535 or worse & $45(7)$ & $32(10)$ \\
\hline \multicolumn{3}{|l|}{ Mean (SD) cholesterol (mmol/l): } \\
\hline Total & $5.5(1.1)$ & $5.6(1.1)$ \\
\hline $\mathrm{HDL}$ & $1.10(0.27)$ & $1.10(0.28)$ \\
\hline LDL & $3.6(1.1)$ & $3.6(1.1)$ \\
\hline $\begin{array}{l}\text { Geometric mean (1SD interval) } \\
\text { triglyceride (mmol/l) }\end{array}$ & $1.6(0.9$ to 2.6$)$ & 1.6 (0.9 to 2.8$)$ \\
\hline $\begin{array}{l}\text { Median duration (interquartile range) } \\
\text { of diabetes (years) }\end{array}$ & 2.7 (1.0 to 4.2$)$ & 2.5 (1.0 to 4.4$)$ \\
\hline \multicolumn{3}{|l|}{ Treatment for diabetes: } \\
\hline Diet & $175(29)$ & $89(29)$ \\
\hline Sulphonylurea & $200(34)$ & $103(34)$ \\
\hline Metformin & $41(8)$ & $23(7)$ \\
\hline Combined oral hypoglycaemic agents & $28(5)$ & $16(5)$ \\
\hline Insulin & $144(23)$ & $70(24)$ \\
\hline Other & $6(1)$ & $1(1)$ \\
\hline
\end{tabular}

$\mathrm{HDL}=$ high density lipoprotein.

$\mathrm{LDL}=$ low density lipoprotein

${ }^{*}$ Corrected to urinary creatinine concentration of $8 \mathrm{mmol} / \mathrm{l}$. 


\section{Treatment protocol}

Randomisation stratified for those with or without previous treatment for hypertension was performed by the coordinating centre. In all 758 patients were allocated tight control of blood pressure, aiming for a blood pressure $<150 / 85 \mathrm{~mm} \mathrm{Hg}$ (400 patients were given an angiotensin converting enzyme inhibitor (captopril) and 358 a $\beta$ blocker (atenolol) as the main treatment); 390 patients were allocated a less tight control of blood pressure, aiming for a blood pressure $<180 / 105 \mathrm{~mm} \mathrm{Hg}$ but avoiding treatment with angiotensin converting enzyme inhibitors or $\beta$ blockers (fig 1). Sealed opaque envelopes were used and checked as described for the UK prospective diabetes study. ${ }^{23}$ The original blood pressure target of $200 / 105 \mathrm{~mm} \mathrm{Hg}$ in the group assigned to less tight control was reduced in 1992 by the steering committee of the hypertension in diabetes study after publication of the results of studies in elderly, non-diabetic subjects during 1991-2. ${ }^{16}{ }^{25} 26$ Randomisation produced balanced numbers of patients allocated to the various glucose and blood pressure treatment combinations for the UK prospective diabetes study and hypertension in diabetes study.

Captopril was usually started at a dose of $25 \mathrm{mg}$ twice daily, increasing to $50 \mathrm{mg}$ twice daily, and atenolol at a daily dose of $50 \mathrm{mg}$, increasing to $100 \mathrm{mg}$ if required. Other agents were added if the control criteria were not met in the group assigned to tight control despite maximum allocated treatment or in the group assigned to less tight control without drug treatment. The suggested sequence was frusemide $20 \mathrm{mg}$ daily (maximum $40 \mathrm{mg}$ twice daily), slow release nifedipine $10 \mathrm{mg}$ (maximum $40 \mathrm{mg}$ ) twice daily, methyldopa $250 \mathrm{mg}$ (maximum $500 \mathrm{mg}$ ) twice daily, and prazosin $1 \mathrm{mg}$ (maximum $5 \mathrm{mg}$ ) thrice daily.

\section{Clinic visits}

Patients visited study clinics every 3-4 months. At each visit plasma glucose concentration, blood pressure, and body weight were measured, and treatments to control blood pressure and blood glucose concentration were noted and adjusted if target values were not met. If treatments and target blood pressures were not in accord with the protocol, the coordinating centre sent letters about affected patients to the clinical centres requesting appropriate action. A central record of all apparent protocol deviations was maintained. Symptoms including any drug side effects and clinical events were noted. Physicians recorded hypoglycaemic episodes as minor if the patient was able to treat the symptoms unaided and as major if third party or medical intervention was necessary.

\section{Blood pressure measurements}

Blood pressure (diastolic phase 5) while the patient was sitting and had rested for at least five minutes was measured by a trained nurse with a Copal UA-251 or a Takeda UA-751 electronic auscultatory blood pressure reading machine (Andrew Stephens, Brighouse, West Yorkshire) or with a Hawksley random zero sphygmomanometer (Hawksley, Lancing, Sussex) in patients with atrial fibrillation. The first reading was discarded and the mean of the next three consecutive readings with a coefficient of variation below $15 \%$ was used in the study, with additional readings if required. Monthly quality assurance measurements have shown the mean difference between Takeda and Hawksley machines to be 1 (4) $\mathrm{mm} \mathrm{Hg}$ or less.

\section{Clinical examination}

At entry to the UK prospective diabetes study and subsequently every three years all patients had a clinical examination which included retinal colour photography, ophthalmoscopy, measurement of visual acuity, assessment of peripheral and autonomic neuropathy, chest radiography, electrocardiography, and measurement of brachial and posterior tibial blood pressure using Doppler techniques. Annual direct ophthalmoscopy was also carried out. Every year a fasting blood sample was taken to measure glycated haemoglobin (haemoglobin $\mathrm{A}_{1 \mathrm{c}}$ ), plasma creatinine concentration, and concentrations of urea, immunoreactive insulin, and insulin antibodies; random urine samples were taken for measurement of albumin concentration.

Visual acuity was measured with Snellen charts until 1989, after which ETDRS (early treatment of diabetic retinopathy study) charts ${ }^{22}$ were used to assess best corrected vision, with current refraction or through a pinhole. Retinal colour photographs of four standard $30^{\circ}$ fields per eye (nasal, disc, macula, and temporal to macular fields) were taken plus stereophotographs of the macula. Repeat photography was arranged if the quality of the photograph was unsatisfactory. Retinal photographs were assessed at a central grading centre by two independent assessors for the presence or absence of diabetic retinopathy. Any fields with retinopathy were graded by two further senior independent assessors using a modified ETDRS final scale. ${ }^{22}$ Neuropathy was assessed clinically by knee and ankle reflexes, and by biothesiometer (Biomedical Instruments, Newbury, Ohio) readings taken from the lateral malleoli and the end of the big toe..$^{22}$ A 12 lead electrocardiogram was recorded and given a Minnesota code, ${ }^{22}$ and a chest $x$ ray film was taken for measurement of cardiac diameter.

\section{Biochemistry}

Biochemical methods have been reported previously. $^{23}$ Urinary albumin concentration was measured by an immunoturbidimetric method with a normal reference range of $1.4 \mathrm{mg} / 1$ to $36.5 \mathrm{mg} / \mathrm{l}^{27}$ Microalbuminuria has been defined as a urinary albumin concentration of $\geqslant 50 \mathrm{mg} / \mathrm{l}^{28}$ and clinical grade proteinuria as a urinary albumin concentration of $\geqslant 300 \mathrm{mg} / \mathrm{l}$.

\section{Clinical end points}

Twenty one clinical end points were predefined in the study protocol. ${ }^{22}$ All available clinical information was gathered for possible end points-for example, copies of admission notes, operation records, death certificates, and necropsy reports. Copies of these, without reference to the patient's allocated or actual treatment, were formally presented to two independent physicians who allocated an appropriate code from the ninth revision of the international classification of diseases (ICD-9) if the criteria for any particular clinical end point had been met. Any disagreement between the two assessors was discussed and the evidence reviewed. If agreement was not possible the information was submitted to a panel of two further 
independent assessors for final arbitration. The closing date for the study was 30 September 1997.

End points were aggregated for the main analyses. The three predefined primary outcome analyses were the time to the occurrence of $(a)$ a first clinical end point related to diabetes (sudden death, death from hyperglycaemia or hypoglycaemia, fatal or non-fatal myocardial infarction, angina, heart failure, stroke, renal failure, amputation (of at least one digit), vitreous haemorrhage, retinal photocoagulation, blindness in one eye or cataract extraction); (b) death related to diabetes (death due to myocardial infarction, sudden death, stroke, peripheral vascular disease, renal disease, hyperglycaemia or hypoglycaemia); (c) death from all causes.

Secondary outcome analyses of four additional aggregates of clinical end points were used to assess the effect of treatments on different types of vascular disease. These were myocardial infarction (fatal or non-fatal myocardial infarction or sudden death), stroke (fatal or non-fatal stroke), amputation or death from peripheral vascular disease, and microvascular complications (retinopathy requiring photocoagulation, vitreous haemorrhage, and fatal or non-fatal renal failure).

Since a patient could in sequence have different end points, he or she could be included in more than one end point category.

Surrogate end points-Details of subclinical, surrogate variables have been published. ${ }^{23}$

\section{Statistical analysis}

Analysis was on an intention to treat basis, comparing patients allocated to tight and less tight blood pressure control. Patients allocated to tight control with angiotensin converting enzyme inhibitors or $\beta$ blockers were pooled in this paper for analysis. They are compared in the accompanying paper. ${ }^{29}$ Life table analyses were performed with log rank tests, and hazard ratios were obtained from Cox's proportional hazards models and used to estimate relative risks. Survival function estimates were calculated using the product limit (Kaplan-Meier) method. In the text relative risks are quoted as risk reductions and significance tests were two sided. For aggregate end points 95\% confidence intervals are quoted, whereas for single end points $99 \%$ confidence intervals are quoted to allow for potential type 1 errors. Similarly, 99\% confidence intervals were used to assess surrogate end points that were measured at triennial visits. Mean (SD), geometric mean (1 SD interval), or median (interquartile range) values are quoted for the biometric and biochemical variables, with values from Wilcoxon, $t$, or $\chi^{2}$ tests for comparisons. Risk reductions for surrogate end points were derived from frequency tables. The overall values for blood pressure during a period were assessed for each patient as the mean during that period and for each allocation as the mean of patients with data in the allocation. Control of blood pressure was assessed in patients allocated to the two groups who had data at nine years of follow up.

Hypoglycaemia was determined from the number of patients allocated to a treatment and continuing with it who had one or more minor or major hypoglycaemic episodes each year. Urinary albumin concentration was measured in $\mathrm{mg} / \mathrm{l}$. Change in diabetic retinopathy was defined as a change of two steps (one step in both eyes or two or more steps in one eye) with a scale from the worse eye to the better eye that included retinal photocoagulation or vitreous haemorrhage as the most serious grade. Visual loss was defined as the best vision in either eye, deteriorating by three lines on an ETDRS chart.

Both the UK prospective diabetes study and hypertension in diabetes study received ethical approval from the appropriate committee in each centre and conformed with the guidelines of the Declarations of Helsinki (1975 and 1983). All patients gave informed consent.

\section{Data monitoring and ethics committee}

The data monitoring and ethics committee examined the end points every six months to consider halting or modifying the study according to predetermined guidelines. These included a difference of three or more standard deviations by log rank test in the rate of deaths related to diabetes or deaths related to diabetes and major illness between the group assigned to tight control and that assigned to less tight control or between the group given captopril and that given atenolol. ${ }^{22}$ One of the stopping criteria was attained immediately before the scheduled end of the study.

\section{Results}

Follow up

The median follow up to death, the last known date at which vital status was known, or to the end of the trial was 8.4 years. The vital status was known at the end of the trial in all patients except $14(1 \%)$ who had emigrated and a further 33 patients $(3 \%)$ who could not be contacted in the last year of the study for assessment of clinical end points.

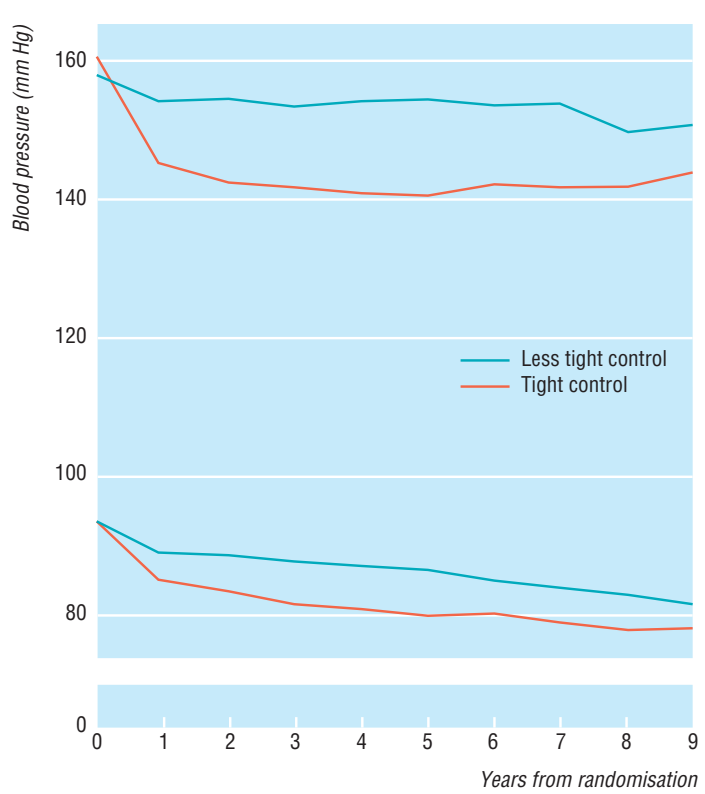

Fig 2 Mean systolic and diastolic blood pressures over nine years in 297 patients in group assigned to tight control of blood pressure and 156 in group assigned to less tight control 


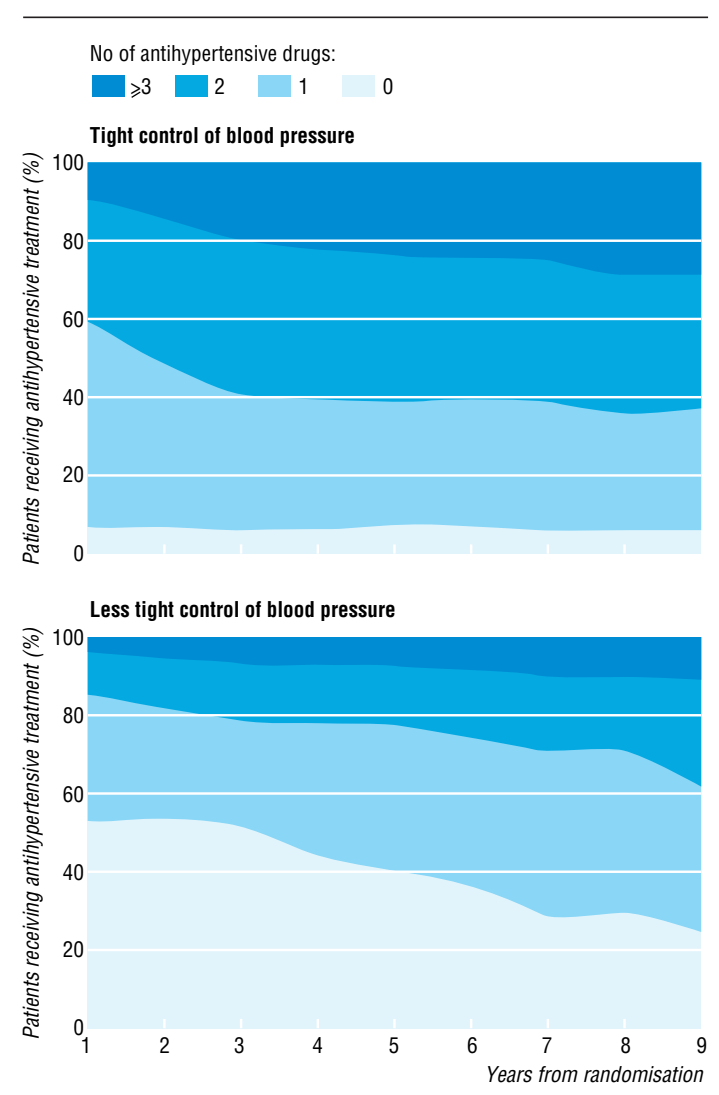

Fig 3 Proportion of patients over nine years who required no drugs, one drug, two drugs, or three or more drugs for treating hypertension to attain target blood pressure

\section{Control of blood pressure}

The mean (SD) blood pressure in the two groups was similar at randomisation (table 1). Mean blood pressure in patients over nine years of follow up was 144 (14)/82 (7) mm Hg in the 297 patients under tight control and $154(16) / 87$ (7) $\mathrm{mm} \mathrm{Hg}$ in the 156 assigned to less tight control $(\mathrm{P}<0.0001$ in both cases $)$ (fig 2). The mean differences in systolic and diastolic pressures were $10(95 \%$ confidence interval 9 to 12$)$ $\mathrm{mm} \mathrm{Hg}$ and 5 (4 to 6 ) $\mathrm{mm} \mathrm{Hg}$ respectively. Cross sec- tional blood pressure in patients with data at each year were similar to the data in patients with nine years of follow up. At nine years the proportion of patients with both a systolic blood pressure of $<150 \mathrm{~mm} \mathrm{Hg}$ and a diastolic blood pressure of $<85 \mathrm{~mm} \mathrm{Hg}$ was $56 \%$ in the group assigned to tight control and $37 \%$ in the group assigned to less tight control. The proportion of patients who had a mean blood pressure of $<180 / 105 \mathrm{~mm} \mathrm{Hg}$ was $96 \%$ and $91 \%$ respectively.

\section{Compliance with allocated treatment}

In the group assigned to tight control of blood pressure patients took their allocated treatment for $77 \%$ of the total person years and did not take antihypertensive treatments for $6 \%$ of the total person years. In the other group patients did not take any antihypertensive treatments for $43 \%$ of the total person years; they took an angiotensin converting enzyme inhibitor for $11 \%$ of the total person years and a $\beta$ blocker for $9 \%$.

Figure 3 shows the increasing number of antihypertensive agents required to maintain blood pressure lower than target levels. At nine years $29 \%$ of those assigned to tight blood pressure control required three or more agents in comparison with $11 \%$ of patients in the other group. The proportion of patients taking nifedipine was $32 \%$ in the group assigned to less tight blood pressure control and $31 \%$ and $40 \%$ in the group assigned to tight blood pressure control taking captopril and atenolol respectively.

\section{Control of blood glucose}

Haemoglobin $\mathrm{A}_{1 \mathrm{c}}$ in the groups assigned to tight and less tight blood pressure control over 1-4 years was $7.2 \%$ and $7.2 \%$ respectively and over 5 - 8 years $8.3 \%$ and $8.2 \%$ respectively.

\section{Aggregate clinical end points}

Any clinical end point related to diabetes

Patients allocated to tight compared with less tight control of blood pressure had a $24 \%$ reduction in risk of developing any end point related to diabetes, $(\mathrm{P}=0.0046)($ figs 4 and 5).

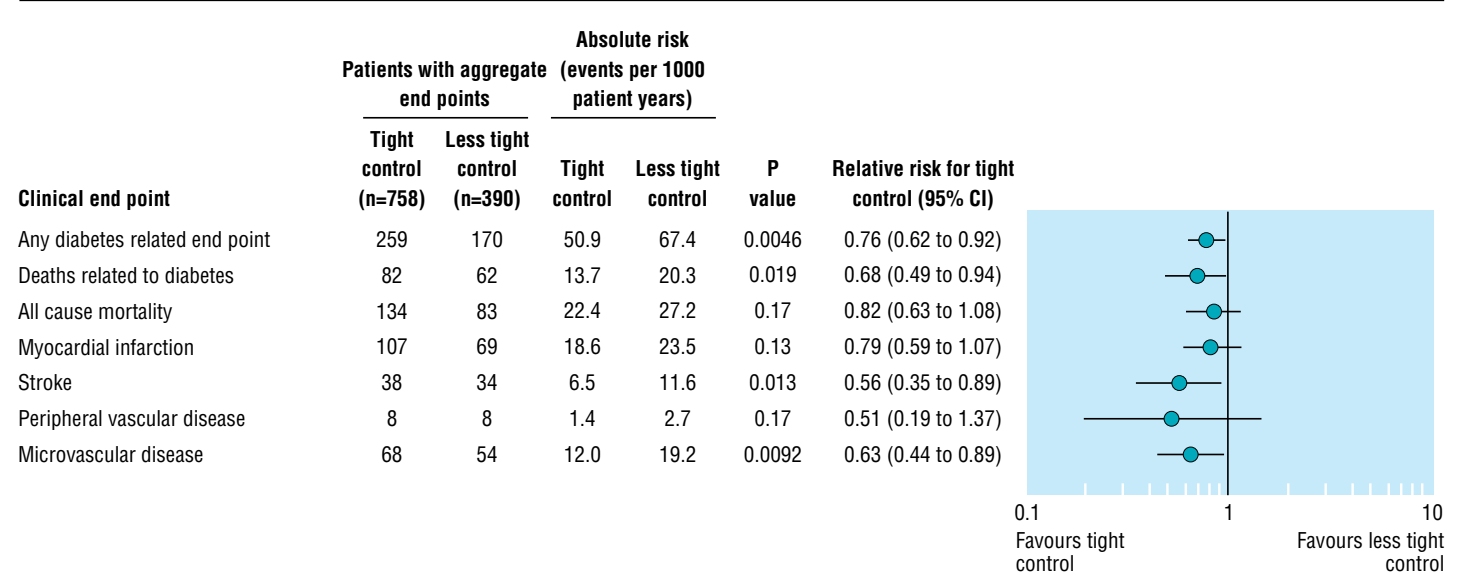

Fig 4 Numbers of patients who attained one or more clinical end points in aggregates representing specific types of clinical complications, with relative risks comparing tight control of blood pressure with less tight control 


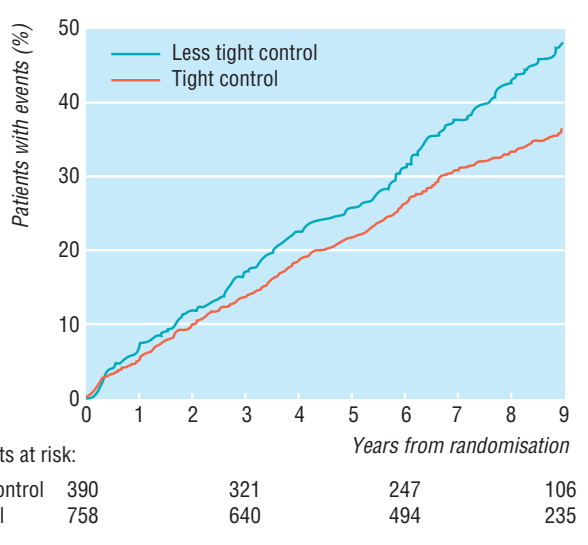

Reduction in risk with tight control $24 \%(95 \% \mathrm{Cl} 8 \%$ to $38 \%)(\mathrm{P}=0.0046)$

Fig 5 Kaplan-Meier plots of proportions of patients with any clinical end point, fatal or non-fatal, related to diabetes

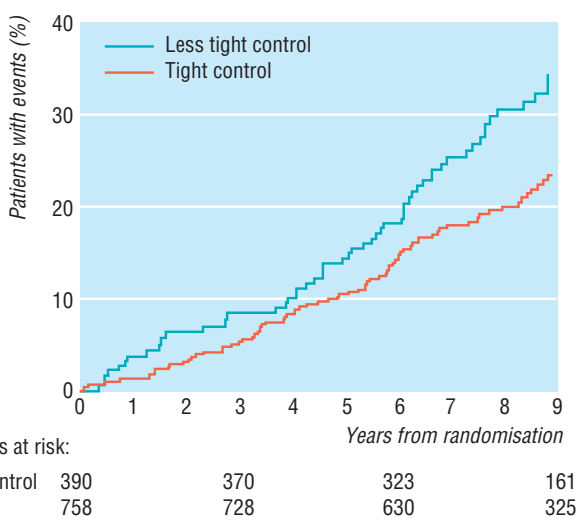

Less tight control 390

Tight control

728

630

161

Reduction in risk with tight control $32 \%(95 \% \mathrm{Cl} 6 \%$ to $51 \%)(\mathrm{P}=0.019)$

Fig 6 Kaplan-Meier plots of proportions of patients who die of disease related to diabetes (myocardial infarction, sudden death, stroke, peripheral vascular disease, and renal failure)

Deaths related to diabetes and all cause mortality

Patients in the group assigned to tight blood pressure control compared with those in the other group had a $32 \%$ reduction in risk of mortality from diseases substantially increased by diabetes $(\mathrm{P}=0.019)$, two thirds of which were cardiovascular diseases. The reduction in all cause mortality was not significant (fig 4). The trend to protection against microvascular disease and death related to diabetes became evident within the first three years of allocation to tight control (figs 4-7).

\section{Myocardial infarction, stroke and peripheral vascular disease}

The group assigned to tight blood pressure control had a non-significant reduction in risk of $21 \%$ in the aggregate end point for myocardial infarction (table 2 and fig 7). This group also had a $44 \%$ reduction in risk of stroke, fatal and non-fatal, compared with the group assigned to less tight blood pressure control $(\mathrm{P}=0.013)$. Amputations were not significantly reduced, with a trend to reductions in risk of $49 \%$. One patient in each group died of peripheral vascular disease.

When all macrovascular diseases were combined, including myocardial infarction, sudden death, stroke, and peripheral vascular disease, the group assigned to tight blood pressure control had a 34\% reduction in risk compared with the group assigned to less tight control $(\mathrm{P}=0.019)$.

\section{Microvascular disease}

The group assigned to tight blood pressure control had a $37 \%$ reduction in risk of microvascular disease compared with the less tight group $(\mathrm{P}=0.0092)$ (figs 4 and 7).

\section{Numbers needed to treat}

The number of patients who needed to be treated over 10 years to prevent one patient developing any complication was 6.1 (95\% confidence interval 2.6 to 9.5) and to prevent death from a cause related to diabetes 15.0 (12.1 to 17.9$)$.

\section{Single clinical end points}

There was a $56 \%$ reduction in risk of heart failure $(\mathrm{P}=0.0043)$ (fig 8$)$ in the tight control group compared with the less tight control group. There was a 35\% reduction in risk of retinal photocoagulation

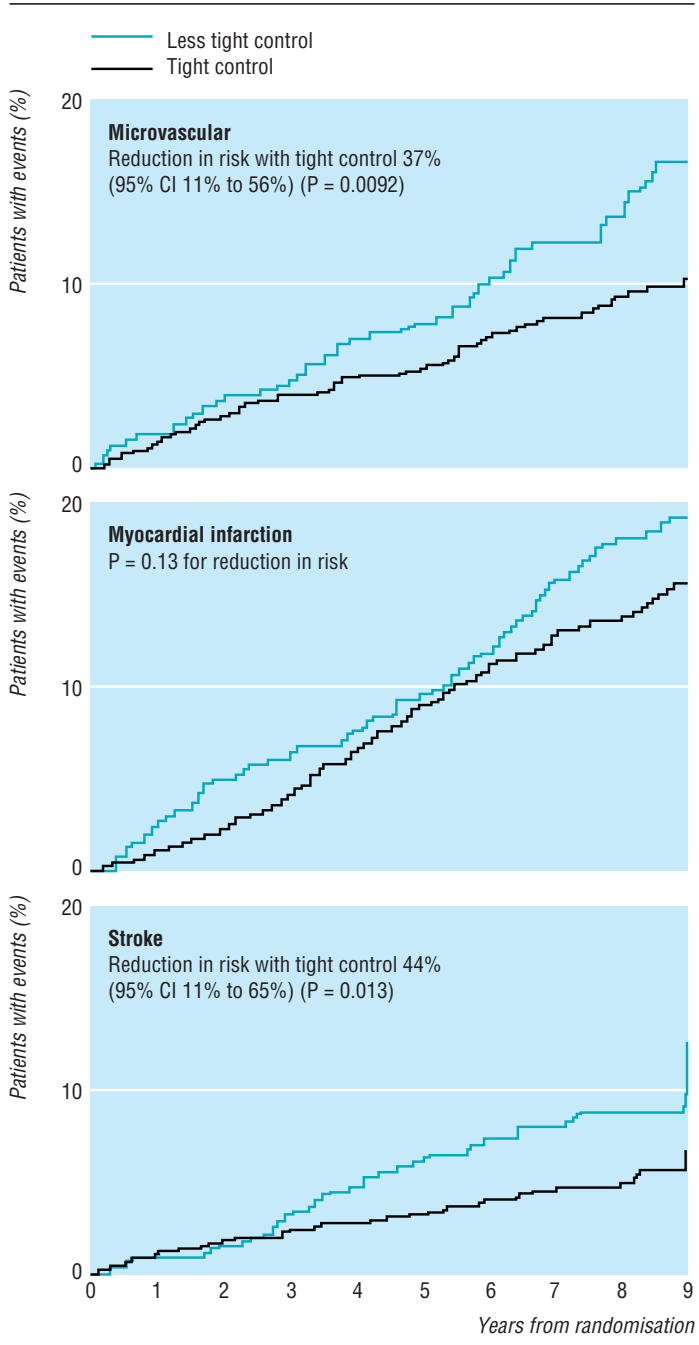

Fig 7 Kaplan-Meier plots of proportions of patients who developed microvascular end points (mostly retinal photocoagulation), fatal or non-fatal myocardial infarction or sudden death, and fatal or non-fatal strokes 


\begin{tabular}{|c|c|c|c|c|c|c|c|c|}
\hline \multirow[b]{2}{*}{ Clinical end point } & \multicolumn{2}{|c|}{$\begin{array}{l}\text { Patients with clinical } \\
\text { end points }\end{array}$} & \multicolumn{2}{|c|}{$\begin{array}{l}\text { Absolute risk } \\
\text { (events per } 1000 \\
\text { patient years) } \\
\end{array}$} & \multirow[b]{2}{*}{$\begin{array}{c}\mathbf{P} \\
\text { value }\end{array}$} & \multirow[b]{2}{*}{$\begin{array}{l}\text { Relative risk for tight } \\
\text { control }(99 \% \mathrm{Cl})\end{array}$} & & \\
\hline & $\begin{array}{l}\text { Tight } \\
\text { control } \\
(\mathrm{n}=758)\end{array}$ & $\begin{array}{l}\text { Less tight } \\
\text { control } \\
(\mathrm{n}=390)\end{array}$ & $\begin{array}{l}\text { Tight } \\
\text { control }\end{array}$ & $\begin{array}{l}\text { Less tight } \\
\text { control }\end{array}$ & & & & \\
\hline Fatal myocardial infarction & 59 & 42 & 9.8 & 13.8 & 0.10 & $0.72(0.43$ to 1.21$)$ & 0 & + \\
\hline Non-fatal myocardial infarction & 51 & 29 & 8.9 & 9.9 & 0.63 & 0.90 (0.49 to 1.63$)$ & & - \\
\hline Sudden death & 11 & 4 & 1.8 & 1.3 & 0.57 & 1.39 (0.31 to 6.26$)$ & & 10 \\
\hline Heart failure & 21 & 24 & 3.6 & 8.1 & 0.0043 & 0.44 (0.20 to 0.94$)$ & 0 & \\
\hline Angina & 45 & 22 & 7.9 & 7.5 & 0.84 & 1.05 (0.54 to 2.06$)$ & & \\
\hline Fatal stroke & 9 & 11 & 1.5 & 3.6 & 0.044 & 0.42 (0.13 to 1.33$)$ & 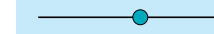 & - \\
\hline Non-fatal stroke & 29 & 26 & 5.0 & 8.9 & 0.029 & 0.56 (0.28 to 1.12$)$ & - & \\
\hline Death from peripheral vascular disease & 1 & 1 & 0.2 & 0.3 & 0.63 & 0.51 (0.01 to 19.64$)$ & & \\
\hline Amputation & 8 & 8 & 1.4 & 2.7 & 0.17 & 0.51 (0.14 to 1.86$)$ & & - \\
\hline Death from renal failure & 2 & 3 & 0.3 & 1.0 & 0.23 & 0.35 (0.03 to 3.66$)$ & & \\
\hline Renal failure & 8 & 7 & 1.4 & 2.3 & 0.29 & 0.58 (0.15 to 2.21 ) & -0 & \\
\hline Retinal photocoagulation & 61 & 47 & 10.2 & 16.6 & 0.023 & 0.65 (0.39 to 1.06$)$ & $-C$ & \\
\hline Vitreous haemorrhage & 3 & 5 & 0.5 & 1.7 & 0.76 & $0.76(0.07$ to 7.95$)$ & - & \\
\hline Blindness in one eye & 18 & 13 & 3.1 & 4.4 & 0.34 & 0.71 (0.28 to 1.81$)$ & -c & 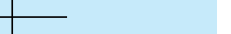 \\
\hline Cataract extraction & 36 & 14 & 6.2 & 4.7 & 0.35 & 1.34 (0.60 to 3.02$)$ & & - \\
\hline Death from hyperglycaemia & 0 & 0 & 0.0 & 0.0 & & & & \\
\hline Death from hypoglycaemia & 0 & 1 & 0.0 & 0.3 & & & & \\
\hline Fatal accident & 1 & 1 & 0.2 & 0.3 & 0.63 & 0.51 (0.01 to 19.44$)$ & & \\
\hline Death from cancer & 29 & 9 & 4.8 & 3.0 & 0.19 & 1.64 (0.62 to 4.39 ) & & 0 \\
\hline Death from any other specified cause & 18 & 10 & 3.0 & 3.3 & 0.82 & 0.92 (0.33 to 2.53 ) & & \\
\hline Death from unknown cause & 4 & 1 & 0.7 & 0.3 & 0.52 & $2.03(0.11$ to 36.13$)$ & 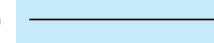 & 0 \\
\hline & & & & & & & $\begin{array}{l}0.1 \\
\text { Favours tight } \\
\text { control }\end{array}$ & $\begin{array}{r}10 \\
\text { Favours less tight } \\
\text { control }\end{array}$ \\
\hline
\end{tabular}

Fig 8 Numbers of patients who attained individual end points, with relative risks comparing tight control of blood pressure with less tight control

$(\mathrm{P}=0.023)$ (fig 8). The trend for reduced risk of fatal and non-fatal renal failure was non-significant (fig 8). There was no significant difference in the incidence of death from accidents, cancer, other specified causes or unknown causes.

\section{Analyses of surrogate end points}

Retinopathy and visual acuity-From median 4.5 years of follow up a smaller proportion of patients in the group assigned to tight blood pressure control showed deterioration in retinopathy from baseline by two or more steps (fig 9), with a $34 \%$ reduction in risk by median 7.5 years $(\mathrm{P}=0.004)$. This was partly because fewer patients required retinal photocoagulation, but the risk was still significantly reduced when retinal photocoagulation was excluded (data not shown). At nine years of follow up the group assigned to tight blood pressure control had a $47 \%$ reduction in risk of a decrease in vision by three or more lines in both eyes measured with an ETDRS chart $(\mathrm{P}=0.004)$ (fig 9). There was no significant difference in the proportion of patients with impaired vision preventing driving (visual acuity $<6 / 12$ Snellen or ETDRS chart $>0.3$ ), although the trend was for a $28 \%$ reduction in risk in the group assigned to tight control $(32 / 371,8.6 \%)$ compared with the group assigned to less tight control $(24 / 201,11.9 \%)(\mathrm{P}=0.20)$.

Microalbuminuria and proteinuria-By six years a smaller proportion of patients in the group under tight blood pressure control had a urinary albumin concentration of $\geqslant 50 \mathrm{mg} / \mathrm{l}$, a $29 \%$ reduction in risk $(\mathrm{P}=0.009)$, with a non-significant $39 \%$ reduction in risk for proteinuria $\geqslant 300 \mathrm{mg} / \mathrm{l}(\mathrm{P}=0.061)$ (fig 9). The reduction in risk for both a urinary albumin concentration of $\geqslant 50 \mathrm{mg} / \mathrm{l}$ and proteinuria at nine years of follow up was not significant. There was no significant difference in plasma creatinine concentra-

Table 2 Comparison of results of hypertension in diabetes study with those of systolic hypertension in elderly programme ${ }^{29}$

\begin{tabular}{|c|c|c|}
\hline & $\begin{array}{l}\text { Hypertension in } \\
\text { diabetes study }\end{array}$ & $\begin{array}{l}\text { Systolic hypertension in } \\
\text { elderly programme }\end{array}$ \\
\hline No of subjects & 1148 & 583 \\
\hline Mean (SD) age (years) & $56(8)$ & $70(6)$ \\
\hline Proportion of men $(\%)$ & 55 & 50 \\
\hline Blood pressure on entry $(\mathrm{mm} \mathrm{Hg})$ & $160 / 94$ & $170 / 76$ \\
\hline Proportion receiving antihypertensive drugs (\%) & 36 & 42 \\
\hline Diabetes entry criterion & $\begin{array}{l}\text { Fasting plasma glucose } \\
>6 \mathrm{mmol} / \mathrm{l} \text { on } \\
2 \text { occasions }\end{array}$ & $\begin{array}{c}\text { Known diabetes or fasting } \\
\text { plasma glucose } \\
\geqslant 7.8 \mathrm{mmol} / \mathrm{l}\end{array}$ \\
\hline Hypoglycaemic treatment & $\begin{array}{l}\text { Diet, oral hypoglycaemic } \\
\text { agents, insulin }\end{array}$ & $\begin{array}{c}\text { Diet, oral hypoglycaemic } \\
\text { agents }\end{array}$ \\
\hline Duration of trial (years) & 9 & 5 \\
\hline Intervention in active group & Captopril or atenolol & $\begin{array}{l}\text { Chlorthalidone with or } \\
\text { without atenolol or } \\
\text { reserpine }\end{array}$ \\
\hline \multicolumn{3}{|l|}{ Blood pressure $(\mathrm{mm} \mathrm{Hg})$ : } \\
\hline Tight control group & $144 / 82$ & $145 / 71$ \\
\hline Less tight control group & $154 / 87$ & $155 / 69$ \\
\hline Difference & $10 / 5$ & $10 / 2$ \\
\hline \multicolumn{3}{|l|}{ Outcome (relative risk $(95 \% \mathrm{Cl})$ ): } \\
\hline Death related to diabetes & 0.68 (0.49 to 0.94$)$ & Not reported \\
\hline $\begin{array}{l}\text { Myocardial infarction, fatal or non-fatal, and } \\
\text { sudden death }\end{array}$ & 0.79 (0.59 to 1.07$)$ & $0.46(0.24$ to 0.88$)$ \\
\hline Stroke, fatal or non-fatal & $0.56(0.35$ to 0.89$)$ & $0.78(0.45$ to 1.34$)$ \\
\hline Microvascular disease & 0.64 (0.44 to 0.91$)$ & Not assessed \\
\hline
\end{tabular}




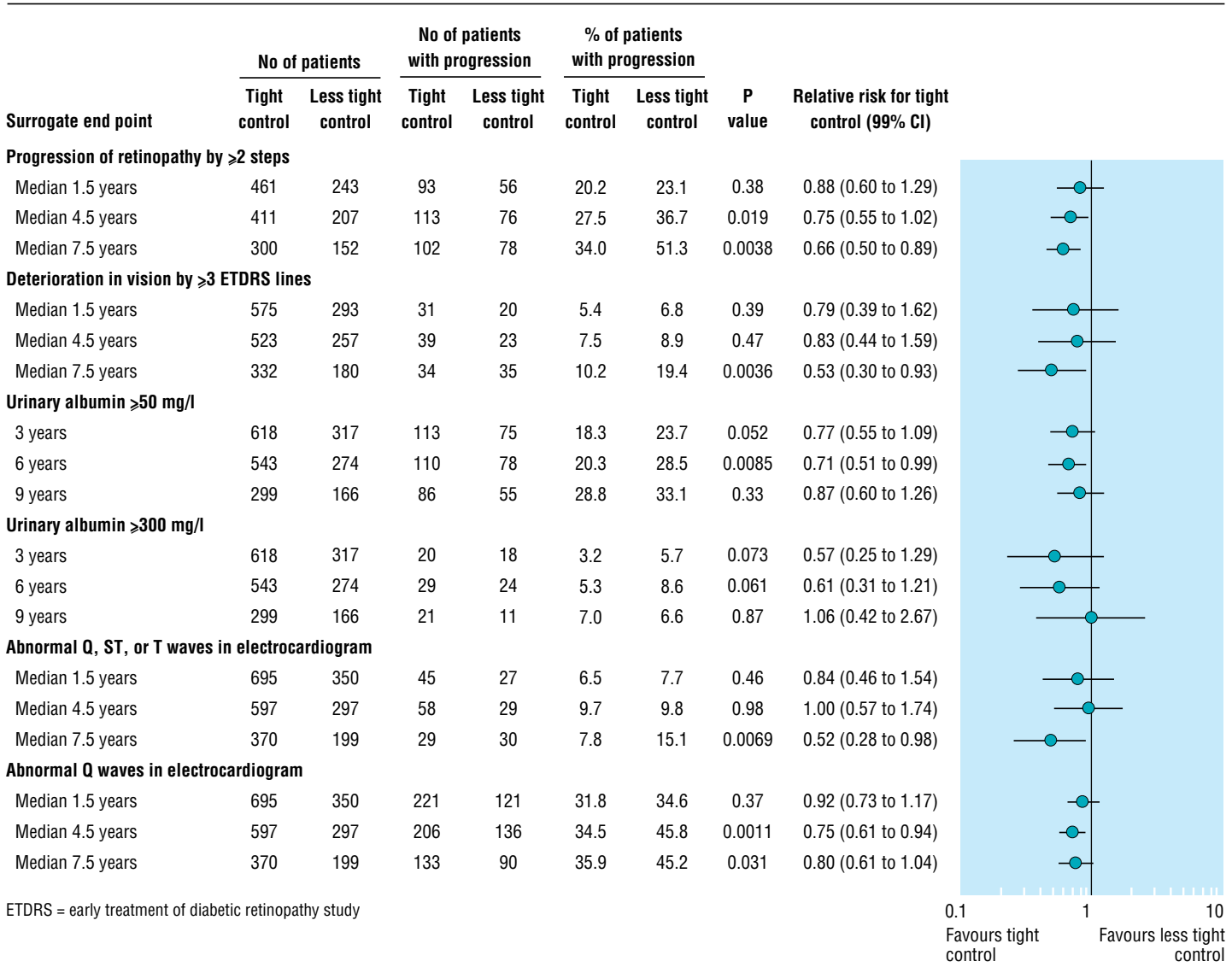

Fig 9 Numbers of patients who attained surrogate end points, with relative risks comparing tight control of blood pressure with less tight control

tion or in the proportion of patients who had a twofold increase in plasma creatinine concentration between the two groups.

Neuropathy-The surrogate indices of neuropathy and autonomic neuropathy were not significantly different between the two groups.

ECG abnormality-By median 7.5 years the tight control group had a lower proportion of $Q$ wave ECG abnormalities than the less tight control group, 29/370 and $30 / 199(7.8 \%$ and $15.1 \%, \mathrm{P}=0.007)$ respectively, a $48 \%$ risk reduction. $\mathrm{ST}$ and $\mathrm{T}$ wave abnormalities were also reduced in the tight control group (fig 9). There was no difference between the allocations for other surrogate indices of macrovascular disease.

There was no significant difference between the groups in the proportion of patients who developed surrogate indices for macrovascular disease.

\section{Side effects}

Hypoglycaemia-There was no significant difference in the cumulative incidence of hypoglycaemia in the groups assigned to tight and less tight blood pressure control, with $6.1 \%$ and $4.4 \%$ respectively having a major hypoglycaemic attack. The cause of death in one patient in the group assigned to less tight control of blood pressure was attibuted to hypoglycaemia.

Weight gain-Mean weight gain was similar in the two groups (1.3 $\mathrm{kg}$ in the group assigned to less tight control and $2.0 \mathrm{~kg}$ in the tight control; $\mathrm{P}=0.13$ ).

\section{Discussion}

This paper reports that patients with hypertension and type 2 diabetes assigned to tight control of blood pressure achieved a significant reduction in risk of $24 \%$ for any end points related to diabetes, $32 \%$ for death related to diabetes, $44 \%$ for stroke, and $37 \%$ for microvascular disease. In addition there was a $56 \%$ reduction in risk of heart failure. The mean blood pressure over nine years was $144 / 82 \mathrm{~mm} \mathrm{Hg}$ on tight control compared with a less tight control mean of $154 / 87 \mathrm{~mm}$ $\mathrm{Hg}$. In comparison, intensive blood glucose control in the UK prospective diabetes study decreased the risk of any diabetes related end point by $12 \%(\mathrm{P}=0.029)$ and microvascular disease by $25 \%(\mathrm{P}=0.0099){ }^{23}$

Comparison of cardiovascular results with other studies-The risk reduction for strokes is similar to results from a meta-analysis of clinical trials of improved blood pressure control in the general population, which showed risk reductions of $42 \%$ for strokes and $12 \%$ for myocardial infarction. ${ }^{14}$ The reduction in cardiovascular end points is in accord with the results of the Systolic Hypertension in the Elderly Program for the 568 patients with non-insulin treated type 2 diabetes whose mean age was 70 and mean blood pressure $170 / 76 \mathrm{~mm} \mathrm{Hg}$ at baseline (table 2). ${ }^{30}$ The Hypertension Optimal Treatment study showed a reduction in cardiovascular mortality for 1501 diabetic patients randomly allocated a target diastolic blood pressure of $\leqslant 80 \mathrm{~mm} \mathrm{Hg},{ }^{31}$ although the blood 
pressures acheived have not been published. Intensive blood pressure control in the diabetic subgroup of the Hypertension Detection and Follw-up Program showed no effect on all cause mortality. ${ }^{32}$

Retinopathy-The was a 34\% reduction in the rate of progression of retinopathy by two or more steps using the modified ETDRS final scale. The $47 \%$ reduction in the deterioration of visual acuity by three lines using the ETDRS chart (equivalent to a change from $6 / 6$ to $6 / 12$ or $6 / 9$ to $6 / 18$ on the Snellen chart) suggests that tight blood pressure control also prevented the development of diabetic maculopathy, which is the main cause of visual impairment in type 2 diabetes. ${ }^{33} \mathrm{In}$ the UK prospective diabetes study diabetic maculopathy occurred in $78 \%$ of patients requiring retinal photocoagulation. As diabetic maculopathy responds less well to laser retinal photocoagulation than proliferative retinopathy, ${ }^{34}{ }^{35}$ reducing the risk of maculopathy by tight blood pressure control might provide a major clinical benefit in reducing the risk of blindness. To our knowledge this is the first report in patients with type 2 diabetes to show that tight blood pressure control reduces the risk of clinical complications from diabetic eye disease.

Renal disease-The proportion of patients in the group assigned to tight blood pressure control who had a urinary albumin concentration of $>50 \mathrm{mg} / \mathrm{l}$ at six years of follow up was only significantly lower than in the group assigned to less tight control at six years follow-up. Good control of blood pressure in patients with renal failure prevents progression of established renal failure in type 1 diabetes. ${ }^{18} 19{ }^{36}$ Ravid et al also showed in 49 normotensive subjects with type 2 diabetes and microalbuminuria (mean $143 \mathrm{mg} / 24 \mathrm{~h}$ (range 30-290)) that improved blood pressure control with enalapril prevented an increase in urine albumin excretion and gave a slower decline in renal function. ${ }^{37}$ Previous epidemiological studies have shown an association between hypertension and albuminuria in patients with type 2 diabetes who do not have renal failure. ${ }^{11} 12$

High blood pressure in type 2 diabetes-Hypertension remains underrecognised and undertreated in the diabetic as well as in the general population. In the 1995 health survey for England 40\% of the general population with hypertension (World Health Organisation criteria: > $160 \mathrm{~mm} \mathrm{Hg}$ systolic, >95 mm Hg diastolic) were not treated and one third of the treated subjects still had a blood pressure greater than 160/95 mm Hg. The mean blood pressure in the group assigned to less tight control of blood pressure in the hypertension in diabetes study over nine years of follow up from a mean age of 56 at recruitment was 154/87 mm Hg. In the second national health and nutrition survey of $1976-80$ in the United States $28 \%$ of hypertensive diabetic patients had blood pressures of $\geqslant 160 \mathrm{~mm} \mathrm{Hg}$ or $\geqslant 95 \mathrm{~mm} \mathrm{Hg}$.

In this study the mean blood pressure in the group assigned to tight blood pressure control was 144/82 mm Hg which is lower than the blood pressures often achieved in hypertensive subjects with or without diabetes. Advisory groups have recommended that the goals for blood pressure in diabetic patients should be $<140 / 90 \mathrm{~mm} \mathrm{Hg},{ }^{38-40}<140 / 85 \mathrm{~mm}$ $\mathrm{Hg}^{41}$ or $<130 / 85 \mathrm{~mm} \mathrm{Hg} .{ }^{42}{ }^{43}$ These recommendations are based on studies in the general population ${ }^{14}$
Key messages

- This study showed that tight control of blood pressure based on captopril or atenolol as first agents and aiming for both a systolic blood pressure $<150 \mathrm{~mm} \mathrm{Hg}$ and diastolic pressure $<85 \mathrm{~mm} \mathrm{Hg}$ achieved a mean 144/82 $\mathrm{mm} \mathrm{Hg}$ compared with $154 / 87 \mathrm{~mm} \mathrm{Hg}$ in a control group

- $29 \%$ of patients in the tight control group required three or more hypotensive treatments

- Tight control of blood pressure reduced the risk of any non-fatal or fatal diabetic complications and of death related to diabetes; deterioration in visual acuity was also reduced

- Reducing blood pressure needs to have high priority in caring for patients with type 2 diabetes

and in patients with type 1 diabetes with microalbuminuria or established nephropathy. ${ }^{18}$ Guidelines were formulated on the assumption that data relating to hypertensive non-diabetic subjects and relatively young patients with type 1 diabetes also applied to those with type 2 diabetes. The prevention of both macrovascular and microvascular disease observed in this study provides evidence for the necessity of tight blood pressure control in type 2 diabetes. The recommendations for the less strict "fair" or "acceptable" blood pressure control targets by some of the advisory groups of $\leqslant 160 / 95 \mathrm{~mm} \mathrm{Hg}$, ${ }^{38}$ $<160 / 90 \mathrm{~mm} \mathrm{Hg}^{40}{ }^{41}$ or $<150 / 90 \mathrm{~mm} \mathrm{Hg}^{39}$ need to be reviewed in the light of the results of our study.

\section{Conclusion}

Hypertension is common in patients with type 2 diabetes, with a prevalence of $40-60 \%$ over the age range of 45 to 75 . This study, embedded within the UK prospective diabetes study, shows that treatment with an angiotensin converting enzyme inhibitor or $\beta$ blocker aiming for a blood pressure of $<150$ / $85 \mathrm{~mm} \mathrm{Hg}$ substantially reduces the risk of death and complications due to diabetes. The management of blood pressure should have a high priority in the treatment of type 2 diabetes.

We appreciate the cooperation of the patients and many NHS and non-NHS staff at the centres. We thank Philip Bassett for editorial assistance, and Caroline Wood, Kathy Waring, and Lorraine Mallia for typing the manuscripts.

Contributors: Clinical centres of the hypertension in diabetes study: M R Stearne, S L Palmer, M S Hammersley, S L Franklin, R S Spivey, J C Levy, C R Tidy, N J Bell, J Steemson, B A Barrow, R Coster, K Waring, L Nolan, E Truscott, N Walravens, L Cook, H Lampard, C Merle, P Parker, J McVittie, I Draisey (Radcliffe Infirmary, Oxford); L E Murchison, A H E Brunt, M J Williams, D W Pearson, X M P Petrie, M E J Lean, D Walmsley, F Lyall, E Christie, J Church, E Thomson, A Farrow, J M Stowers, M Stowers, K McHardy, N Patterson (Royal Infirmary, Aberdeen); A D Wright, N A Levi, A C I Shearer, R J W Thompson, G Taylor, S Rayton, M Bradbury, A Glover, A Smyth-Osbourne, C Parkes, J Graham, P England, S Gyde, C Eagle, B Chakrabarti, J Smith, J Sherwell (Birmingham General Hospital); E M Kohner, A Dornhorst, M C Doddridge, M Dumskyj, S Walji, P Sharp, M Sleightholm, G Vanterpool, C Rose, G Frost, M Roseblade, S Elliott, S Forrester, M Foster, K Myers, R Chapman (Hammersmith Hospital, London); J R Hayes, R W Henry, M S Featherston, G P R Archbold, M Copeland, R Harper, I Richard- 
son, S Martin, M Foster, H A Davison, (City Hospital, Belfast); D R Hadden, L Kennedy, A B Atkinson, A M Culbert, C Hegan, H Tennet, N Webb, I Robinson, J Holmes, M Foster, P M Bell, D R McCance, J Rutherford, S Nesbitt (Royal Victoria Hospital, Belfast); A S Spathis, S Hyer, M E Nanson, L M James, J M Tyrell, C Davis, P Strugnell, M Booth, H Petrie, D Clark, B Rice, S Hulland, J L Barron (St Helier Hospital, Carshalton); J S Yudkin, B J Gould, J Singer, A Badenock, S Walji, M Eckert, K Alibhai, E Marriot, C Cox, R Price, M Fernandez, A Ryle, S Clarke, G Wallace, E Mehmed, S MacFarlane (Whittington Hospital, London); R H Greenwood, J Wilson, M J Denholm, R C Temple, K Whitfield, F Johnson, C Munroe, S Gorick, E Duckworth, M Flatman, S Rainbow (Norfolk and Norwich Hospital, Norwich); L J Borthwick, D J Wheatcroft, R J Seaman, R A Christie, W Wheatcroft, P Musk, J White, S McDougal, M Bond, P Raniga (Lister Hospital, Stevenage); R W Newton, R T Jung, C Roxburgh, B Kilgallon, L Dick, M Foster, N Waugh, S Kilby, A Ellingford, J Burns (Ninewells Hospital, Dundee); C V Fox, M C Holloway, H M Coghill, N Hein, A Fox, W Cowan, M Richard, K Quested, S J Evans (Northampton Hospital); R B Paisey, N P R Brown, A J Tucker, R Paisey, F Garrett, J Hogg, P Park, K Williams, P Harvey, R Wilcocks, S Mason, J Frost, C Warren, P Rocket, L Bower (Torbay Hospital); J M Roland, D J Brown, J Youens, K Stanton-King, H Mungall, V Ball, W Maddison, D Donnelly, S King, P Griffin, S Smith, S Church, G Dunn, A Wilson, K Palmer (Peterborough General Hospital); P M Brown, D Humphriss, A J M Davidson, R Rose, L Armistead, S Townsend, P Poon (Scarborough Hospital); I D A Peacock, NJ C Culverwell, M H Charlton, B P S Connolly,J Peacock, J Barrett, J Wain, W Beeston, G King, P G Hill (Derbyshire Royal Infirmary, Derby); A J M Boulton, A M Robertson, V Katoulis, A Olukoga, H McDonald, S Kumar, F Abouaesha, B Abuaisha, E A Knowles, S Higgins, J Booker, J Sunter, K Breislin, R Parker, P Raval, J Curwell, H Davenport, G Shawcross, A Prest, J Grey, H Cole, C Sereviratne (Manchester Royal Infirmary); R J Young, T L Dornan, J R Clyne, M Gibson, I O'Connell, L M Wong, S J Wilson, K L Wright, C Wallace, D McDowell (Hope Hospital, Salford); A C Burden, E M Sellen, R Gregory, M Roshan, N Vaghela, M Burden, C Sherriff, J Clarke, J Grenfell (Leicester General Hospital); J E Tooke, K MacLeod, C Searnark, M Rammell, C Pym, J Stockman, C Yeo, J Piper, L Leighton, E Green, M Hoyle, K Jones, A Hudson, A J James, A Shore, A Higham, B Martin (Royal Devon and Exeter Hospital, Exeter).

Coordinating centre: R C Turner, R R Holman (chief investigators); D R Matthews, H A W Neil (additional investigators); I M Stratton, C A Cull, H J McElroy, Z Mehta (statisticians); S E Manley (biochemist); V Frighi (research associate); R Peto (consultant statistician); A I Adler (epidemiologist); P A Bassett (administrator); D R Matthews (Oxford), A D Wright (Birmingham), T L Doman (Salford) (end point assessors); E M Kohner, S Aldington, H Lipinski, R Collum, K I Harrison, C Macintyre, S Skinner, A Mortemore, D Nelson, S Cockley, S Levien, L Bodsworth, R Willox, T Biggs, S Dove, E Beattie, M Gradwell, S Staples, R Lam, F Taylor, L Leung (retinal photography grading); M J Payne, R D Carter, S M Brownlee, K E Fisher, K Islam, R Jelfs, P A Williams, F A Williams, P J Sutton, A Ayres, L J Logie, M A Evans, L A Stowell (laboratory staff); E A Eeley (Oxford) (dietitian); I Ross (Aberdeen) (consultant biochemist); I A Kennedy (applications programmer); D Croft, E A Harris (database clerks); A H Keen, C Rose (Guy's Hospital) (electrocardiographic coding); M Raikou, A M Gray, A J McGuire, P Fenn (Oxford) (health economists); Z Mehta (Oxford), A E Fletcher, C Bulpitt, C Battersby (Hammersmith), J S Yudkin (Whittington) (quality of life questionnaire); R Stevens (Oxford) (mathematical modeller).

Previous participants: S F Oakes (administrator); J I Mann (epidemiologist); A Smith, Z Nugent (statisticians).

Committees: C A Cull, V Frighi, R R Holman, S E Manley, D R Matthews, H A W Neil, I M Stratton, R C Turner (United Kingdom prospective diabetes study data committee); W J H Butterfield, W R S Doll, R Eastman, F R Ferris, R R Holman, N Kurinij, R Peto, K McPherson, R F Mahler, T W Meade, G Shafer, R C Turner, P J Watkins, D Siegel (previous member) (Data monitoring and ethics committee). C V Fox, D R Hadden, R R Holman, D R Matthews, R C Tumer, A D Wright, J S Yudkin (Policy Advisory Group). A B Atkinson, R R Holman, J G G Ledingham, L E Ramsay, R C Turner, A E G Raine (previous member) (Steering Committee for Hypertension in Diabetes Study). D J Betteridge, R D Cohen, D Currie, J Darbyshire, J V Forrester, T Guppy, R R Holman, D G Johnston, A McGuire, M
Murphy, A M el-Nahas, B Pentecost, D Spiegelhalter, R C Turner (Medical Research Council and British Diabetic Association steering committee).

Guarantor: R C Turner.

Funding: The UK prospective diabetes study and the hypertension in diabetes study was funded by grants from the Medical Research Council, British Diabetic Association, Department of Health, the United States National Eye Institute and the United States National Institute of Diabetes, Digestive and Kidney Disease in the National Institutes of Health, the British Heart Foundation, the Charles Wolfson Charitable Trust, the Clothworkers' Foundation, the Health Promotion Research Trust, the Alan and Babette Sainsbury Trust, the Oxford University Medical Research Fund Committee, and pharmaceutical companies, including Novo-Nordisk, Bayer, Bristol-Myers Squibb, Hoechst, Lilly, Lipha, and Farmitalia Carlo Erba. GlaxoWellcome, SmithKline Beecham, Pfizer, Zeneca, Pharmacia and Upjohn, and Roche provided grants for health economics and epidemiological studies. Boehringer Mannheim, Becton Dickinson, Owen Mumford, Securicor, Kodak, and Cortecs Diagnostics gave additional help.

Conflict of interest: None.

1 Garcia MJ, McNamara PM, Gordon T, Kannell WB. Morbidity and mortality in diabetics in the Framingham population. Sixteen year follow-up Diabetes 1974;23:105-11.

2 Stamler J, Vaccaro O, Neaton JD, Wentworth D. Diabetes, other risk factors, and 12 year cardiovascular mortality for men screened in the multiple risk factor intervention trial. Diabetes Care 1993;16:434-44.

3 Manson JAE, Colditz GA, Stampfer MJ, Willett WC, Krolewski AS, Rosner B, et al. A prospective study of maturity-onset diabetes mellitus and risk of coronary heart disease and stroke in women. Arch Intern Med 1991;151:1141-7.

4 Perneger TV, Brancati FL, Whelton PK, Klag MJ. End-stage renal disease attributable to diabetes mellitus. Ann Intern Med 1994;121:912-8.

5 Klag MJ, Whelton PK, Randall BL, Neaton JD, Brancati FL, Ford CE, et al. Blood pressure and end stage renal disease in men. $N$ Engl J Med 1996;334:13-8.

6 United Kingdom Prospective Diabetes Study Group. UK Prospective Diabetes Study 23: risk factors for coronary artery disease in non-insulin dependent diabetes. BMJ 1998;316:823-8.

7 Hypertension in Diabetes Study Group. HDS 1: Prevalence of hypertension in newly presenting type 2 diabetic patients and the association with risk factors for cardio-vascular and diabetic complications. J Hypertens 1993;11:309-17.

8 Prescott-Clarke P, Primatesta P, eds. Health survey for England 1995. London: HMSO, 1997.

9 Harris MI, Cowie CC, Stern MP, Boyko EJ, Reiber GE, Bennett PH, eds. Diabetes in America. 2nd ed. Washington, DC: National Institutes of Health, National Institute of Diabetes and Digestive and Kidney Diseases, 1995.

10 Hypertension in Diabetes Study Group. HDS 2: Increased risk of cardio-vascular complications in hypertensive type 2 diabetic patients. J Hypertens 1993;11:319-25.

11 United Kingdom Prospective Diabetes Study Group. UK Prospective Diabetes Study X: urinary albumin excretion over 3 years in diet-treated type 2 (non-insulin-dependent) diabetic patients, and association with hypertension, hyperglycaemia and hypertriglyceridaemia. Diabetologia 1993;36:1021-9.

12 Nelson RG, Bennett PH, Beck GJ, Tan M, Knowler WC, Mitch WE, et al. Development and progression of renal disease in Pima Indians with noninsulin-dependent diabetes mellitus. N Engl J Med 1996;335:1636-42.

13 United Kingdom Prospective Diabetes Study Group. UK Prospective Diabetes Study 30: diabetic retinopathy at diagnosis of type 2 diabetes and associated risk factors. Arch Ophthalmol 1998;116:297-303.

14 Collins R, MacMahon S. Blood pressure, antihypertensive drug treatment and the risks of stroke and of coronary heart disease. Br Med Bull 1994;50:272-98.

15 Collins R, Peto R, MacMahon S, Herbert P, Fiebach NH, Eberlein KA, et al. Blood pressure, stroke, and coronary heart disease. Part 2. Short-term reductions in blood pressure: overview of randomised drug trials in their epidemiological context. Lancet 1990;335:827-38.

16 Medical Research Council Working Party. MRC trial of treatment of hypertension in older adults: principal results. BMJ 1992;304:405-12.

17 Sanderson S. Hypertension in the elderly: pressure to treat? Health Trends 1996;28: 4:117-21.

18 Parving HH, Andersen M, Smidt UH, Hommel E, Mathiesen ER, Svendsen PA. Effect of antihypertensive treatment on kidney function in diabetic nephropathy. BMJ 1987;294:1443-7.

19 Mogensen C, Keane W, Bennett P, Jerums G, Parving H, Passa P, et al. Prevention of diabetic renal disease with special reference to microalbuminuria. Lancet 1995;346:1080-4.

20 Mogensen CE. Systemic blood pressure and glomerular leakage with particular reference to diabetes and hypertension. I Intern Med 1994;235:297-316

21 Hypertension in Diabetes Study Group. HDS 3: Prospective study of therapy in type 2 diabetic patients-efficacy of ACE inhibitor and ß-blocker. Diabet Med 1994;11:773-82.

22 United Kingdom Prospective Diabetes Study Group. UK prospective diabetes study VIII: study design, progress and performance. Diabetologia 1991;34:877-90. 
23 United Kingdom Prospective Diabetes Study Group. UK prospective diabetes study 33: intensive blood glucose control with sulphonylureas or insulin compared with conventional treatment and risk of complication in patients with type 2 diabetes Lancet 1998;352:837-53.

24 British Diabetic Association. Dietary recommendations for diabetics for the 1980s. Hum Nutr Appl Nutr 1982;36:378-94.

25 Systolic Hypertension in the Elderly Program Cooperative Research Group. Prevention of stroke by antihypertensive drug treatment in older persons with isolated systolic hypertension. Final results of the systoli hypertension in the elderly program (SHEP). JAMA 1991;265:3255-64.

26 Dahlof B, Lindholm L, Hansson L, Scheriten B, Ekbom T, Wester PO. Morbidity and mortality in the Swedish trial in old patients with hypertension (STOP-Hypertension). Lancet 1991;338:1281-5.

27 United Kingdom Prospective Diabetes Study Group. UK Prospective Diabetes Study XI: biochemical risk factors in type 2 diabetic patients at diagnosis compared witn age-matched normal subjects. Diabet Med 1994;11:534-44.

28 Manley SE, Burton ME, Fisher KE, Cull CA, Tumer RC. Decreases in albumin/creatinine and $\mathrm{N}$-acetylglucosaminidase/creatinine ratios in urine samples stored at $-20^{\circ} \mathrm{C}$. Clin Chem 1992;38:2294-9.

29 UK Prospective Diabetes Study Group. Efficacy of atenolol and captopril in reducing risk of macrovascular and microvascular complications in type 2 diabetes: UKPDS 39. BMJ 1998;317:713-20.

30 Curb JD, Pressel SL, Cutler JA, Savage P, Applegate WB, Black H, et al. Effect of diuretic-based antihypertensive treatment on cardiovascular disease risk in older diabetic patients with isolated systolic hypertension. Systolic Hypertension in the Elderly Program Cooperative Research Group. JAMA 1996;276:1886-92.

31 Hansson L, Zanchetti A, Carruthers SG, Dahlf B, Elmfeldt D, Julius S, et al. Effect of intensive blood-pressure lowering and low-dose aspirin in patients with hypertension: principal results of the hypertension optimal treatment (HOT) randomised trial. Lancet 1998;351:1755-62.

32 Hypertension Detection and Follow-up Program Cooperative Group Mortality findings for stepped-care and referred-care participants in the
Hypertension Detection and Follow-up Program, stratified by other risk factors. Preo Med 1985; 14:312-35

33 Klein R, Moss SE, Klein BE, Davis MD, DeMets DL. The Wisconsin Epidemiologic Study of Diabetic Retinopathy. XI. The incidence of macular edema. Ophthalmology 1989;96:1501-10.

34 Davies EG, Petty RG, Kohner EM. Long term effectiveness of photocoagulation for diabetic maculopathy. Eye 1989:3:764-7.

35 British Multicentre Group. Photocoagulation for proliferative diabetic retinopathy: a randomised controlled clinical trial using the xenon-arc. Diabetologia 1984;26:109-15.

36 Parving HH, Hommel E, Smidt UM. Protection of kidney function and decrease in albuminuria by captopril in insulin dependent diabetics with nephropathy. BMJ 1987;297:1086-91.

37 Ravid M, Savin H, Jutrin I, Bental T, Lang R, Lishner M. Long-term effect of ACE inhibition on development of nephropathy in diabetes mellitus type II. Kidney Int 1994;45(suppl):S161-4.

38 Alberti KGMM, Gries FA, Jervell J, Krans HM. A desktop guide for the management of non-insulin-dependent diabetes mellitus (NIDDM): an update. Diabetic Med 1994;11:899-909.

39 Canadian Diabetes Advisory Board. Clinical practice guidelines. Can Med Assoc J 1992;147:697-712.

40 Bauduceau B, Chatellier G, Cordonnier D, Marre M, Mimran A, Monnier $\mathrm{L}$, et al. Hypertension arterielle et diabète. Membres des conseils d'administration et scientifiques de l'ALFEDIAM. Diabetes Metab 1996;22:64-76.

41 RR Associates. Blood pressure and diabetes: everyone's concern. London: British Diabetic Association, 1994.

42 American Diabetes Association. Standards of medical care for patient with diabetes mellitus. Diabetes Care 1998;21(suppl):S23-31.

43 Joint National Committee on Prevention, Detection, Evaluation and Treatment of High Blood Pressure. Sixth report. Arch Intern Med $1997: 157: 2413-46$

(Accepted 17 August 1998)

\title{
Efficacy of atenolol and captopril in reducing risk of macrovascular and microvascular complications in type 2 diabetes: UKPDS 39
}

\author{
UK Prospective Diabetes Study Group
}

\begin{abstract}
Objective: To determine whether tight control of blood pressure with either a $\beta$ blocker or an angiotensin converting enzyme inhibitor has a specific advantage or disadvantage in preventing the macrovascular and microvascular complications of type 2 diabetes.

Design: Randomised controlled trial comparing an angiotensin converting enzyme inhibitor (captopril) with a $\beta$ blocker (atenolol) in patients with type 2 diabetes aiming at a blood pressure of

$<150 /<85 \mathrm{~mm} \mathrm{Hg}$.

Setting: 20 hospital based clinics in England, Scotland, and Northern Ireland.

Subjects: 1148 hypertensive patients with type 2 diabetes (mean age 56 years, mean blood pressure $160 / 94 \mathrm{~mm} \mathrm{Hg}$ ). Of the 758 patients allocated to tight control of blood pressure, 400 were allocated to captopril and 358 to atenolol. 390 patients were allocated to less tight control of blood pressure. Main outcome measures: Predefined clinical end points, fatal and non-fatal, related to diabetes, death related to diabetes, and all cause mortality. Surrogate measures of microvascular and macrovascular disease included urinary albumin excretion and retinopathy assessed by retinal photography.

Results: Captopril and atenolol were equally effective in reducing blood pressure to a mean of 144/83 $\mathrm{mm} \mathrm{Hg}$ and 143/81 $\mathrm{mm} \mathrm{Hg}$ respectively, with a similar proportion of patients (27\% and $31 \%)$ requiring three or more antihypertensive treatments.
\end{abstract}

More patients in the captopril group than the atenolol group took the allocated treatment: at their last clinic visit, $78 \%$ of those allocated captopril and $65 \%$ of those allocated atenolol were taking the drug $(\mathrm{P}<0.0001)$. Captopril and atenolol were equally effective in reducing the risk of macrovascular end points. Similar proportions of patients in the two groups showed deterioration in retinopathy by two grades after nine years (31\% in the captopril group and $37 \%$ in the atenolol group) and developed clinical grade albuminuria $\geqslant 300 \mathrm{mg} / 1$ ( $5 \%$ and $9 \%)$. The proportion of patients with hypoglycaemic attacks was not different between groups, but mean weight gain in the atenolol group was greater $(3.4 \mathrm{~kg} v 1.6 \mathrm{~kg})$.

Conclusion: Blood pressure lowering with captopril or atenolol was similarly effective in reducing the incidence of diabetic complications. This study provided no evidence that either drug has any specific beneficial or deleterious effect, suggesting that blood pressure reduction in itself may be more important than the treatment used.

\section{Introduction}

Most randomised controlled trials of treatment for hypertension in patients with diabetes have evaluated blood pressure lowering in comparison with a conventionally treated group of patients who had higher blood pressure. ${ }^{1}$ These trials mainly used a single agent rather than comparing blood pressure lowering with different agents.
Editorials by Orchard and Mogensen Papers pp 703, 720

Members of the study group are given at the end of the accompanying paper on $\mathrm{p} 703$.

This paper was prepared for publication by Rury Holman, Robert

Turner, Irene

Stratton, Carole

Cull, Valeria Frighi, Susan Manley,

David Matthews,

Andrew Neil, Eva

Kohner, David

Wright, David

Hadden, and

Charles Fox.

Correspondence to: Professor R

Holman,

UK Prospective

Diabetes Study

Group, Diabetes

Research

Laboratories,

Radcliffe Infirmary,

Oxford OX2 6HE

BMJ 1998;317:713-20 